\title{
Identifying Potential Estate Commodity for Agropolitan Development in Ponorogo
}

\author{
Pawana Nur Indah \\ Department of Agribussines, Faculty of Agriculture, Universitas Pembangunan Nasional Veteran \\ Jawa Timur (UVJT), Indonesia. Rungkut Madya Gunung Anyar, Surabaya, Indonesia \\ Tel. +62 318706369 Fax. +62 318706369 E-mail : pawana_ni@upnjatim.com \\ Zainal Abidin Sam \\ Department of Agribussines, Faculty of Agriculture, Universitas Pembangunan Nasional Veteran \\ Jawa Timur (UVJT), Indonesia. Rungkut Madya Gunung Anyar, Surabaya, Indonesia \\ Tel. +62 318706369 Fax. +62 318706369 E-mail : z_abidinsa@yahoo.com \\ Effi Damaijati \\ Department of Agribussines, Faculty of Agriculture, Universitas Pembangunan Nasional Veteran \\ Jawa Timur (UVJT), Indonesia. Rungkut Madya Gunung Anyar, Surabaya, Indonesia \\ Tel. +62 318706369 Fax. +62 318706369 E-mail : fidamic@yahoo.com
}

(Received: Mar 29, 2017; Reviewed: Apr 20, 2017; Accepted: Jun 9, 2017)

\section{DOI: http://dx.doi.org/10.20956/ijas.v5i1.1171}

\begin{abstract}
Agropolitan development concept appear from the gap with urban development as a center of economic activity and growth in the rural areas as agricultural activity center left. Rural areas with agricultural activities, which are always experiencing decline productivity, on the other side of the urban area as a destination market and growth centers receive overload that led to the discomfort caused by the conflict, crime, disease, pollution and poor sanitation neighborhoods. The specific objective of the study was to identify potential estate commodity in supporting agropolitan development. Getting a plate form agribusiness competitiveness through agropolitan using Location Quotien (LQ) Method. The results show that several comodities namely coconut, cocoa, dairy, red onion, which have a high LQ value. Development agropolitan can improve equitable development refers to agricultural revitalization program, given the selected sector is the basis of community activity.
\end{abstract}

Keywords: LQ; agropolitan; estate commodity

\section{Introduction}

The concept of agropolitan development problems appear from the gap between the region's development as a center of the city, and the economic growth of rural areas as agricultural activity center left. According to (Muhammadi et al., 2015) development of the city as a center of growth is not give effect to the hatch down (trickle down effect), but it was a cause of resource depletion ef- fects of the surrounding area (backwash effect). (Friedmann, 2005) In other words, there has been economic in net transfer of resources from rural areas to urban areas on a large scale (Douglass, 1981) and It is still very important in pro-poor policy interventions. This is a reason why the Indonesian government should prioritize the revitalization of agriculture development (Arsyad, 2010) through the process of community 
development, consisting of: created social conditions conducive, strengthen economic potential, and protect people from his own weaknesses (Bahua et al., 2016).

Development agribusiness system and food security is the target of agricultural development (Afgani et al., 2012). The results of empirical relationships village-city development strategy in perspective agropolitan in supporting the development ofagri-based economy of the regioncan be formulated some anticipation issues ( $\mathrm{Li}, 2009)$. In many cases, rural impoverishment, increasing income disparity and environmental degradation and hamper the sustainability of agriculture and rural development (Thayib, 2010).

Agropolitan development concept was first introduced Mc. Douglass and Fried mannin (Pasaribu, 1999) as astrategy for rural development. System development and agribusiness and food security is the goal, and once the target of agricultural development (Apriyanto, 2008). Agribusiness development in order to provide benefits and maximum impact foreconomic development an dimprovement of local people's income, it needs a new approach in the development of agribusiness in the field (Krisnamurthi, 2005). Considered an effective approach is to synergize the development of agribusiness in the context ofregional economic development, so thatthe totalvalue added agribusiness development can been joyed by the local community is generally referred to as development agropolitan (David and Erickson, 1987).

Agropolitan development also meant that the service center of agricultural activities (agribusiness) is very close to the set- tlement of farmers, both service regarding cultivation techniques and working capital credit system services and market in formation. Thus, information can be received so that the changes can be anticipated.

Agropolitan are a consist so farm town and villages agricultural production centers are nearby, where the agricultural are a has facilities like urban. Agropolitan basically amove menttore-build the village. Good village should ideally be able to be a place that is comfortable, dignified and prosperous society. Do not assume that the village should be developed that city. However, making the village in to a decent place. This creates idea of Agropolitan (Hamenda, 2007). The concept of this agropolitan base on the build farm town functions in a broad sense. Where agriculture was not seen on the side of planting and hoeing saja.in agropolitan here must be industry, services, tourism, and so on, but the agricultural base in the broadest sense (BAPPENAS, 2007).

Concept development agropolitan not a new concept but it is optimizing development out comes in selected are a seitherin the form of Regions Production Centers (RPC), Integrated Economic Development Zone (IEDZ) and certain other priority areas. It should be noted that the concept of development agropolitan also include optimization ofthe results of programs that have already implemented such as: Guidance program, Plantation Society Industrial Area Program (IAP), Animal Husbandry Enterprise Zone Program (AEZP), Program Provision of Rural Infrastructure (PPSD) and the Districts, Development Program (KDP). Thus, the development program should be complementa- 
ry Agropolitan Regions and synergistic with both programs originating from the central, provincial and district/city. Agropolitan area development is integrated to plan in order to obtain maximum efficiency and effectiveness in the implementation of it's development (Hamenda, 2007). Purpose of location quotion analysis is to determine the pre-eminent commodity in an area. Which stands on the concept of efficiency to achieve comparative and competitive advantage in terms of supply or demand. The specific objective of this study was to identifying potential estate commodity in supporting agropolitan development.

\section{Method}

\subsection{Location quotient analysis}

Location Queotion (LQ) is an index for comparing the commodity at the district level in Ponorogo. More operational, LQ is defined as the ratio of the percentage of the total activity of agriculture observed.

The formula of LQ is:

Where:

$$
\mathrm{LQ}=\left(\mathrm{X}_{\mathrm{ij}} / \mathrm{X}_{\mathrm{i}}\right) /\left(\mathrm{X}_{\mathrm{ij}} / \mathrm{X}_{\mathrm{j}}\right)
$$

$\mathrm{Xij}=$ production of kinds of commodities until in the district

$\mathrm{Xi}=$ total production of commodity farming the district

$\mathrm{Xj}=$ total production of kinds of commodities untilj

$\mathrm{X}=$ the total production of commodity farming district

\subsection{Interpretation of the value of $L Q$}

To be able to interpret the results of the analysis of LQ, then:

(1) If the value of $L Q>1$, indicating a concentration of agricultural production district level relative to the total concentration of the district or the activity happening in the District. Or a surplus commodity production in the district and is a sector basis in the District; (2) If the value of $L Q=1$, then the subdistrict has agricultural activity equivalent to the District; (3) If the value of $\mathrm{LQ}<1$, then the sub-district in Ponorogo have a relatively smaller share than the district agricultural activity, or there has been a production deficit in the district.

\section{Results and Discussion}

Development Analysis of agricultural commodities in Ponorogo will be explained below. Ponorogo is located as strategic position in the development of agropolitan in East Java Province. This strategic position include: skipped national and transportation routeslinking the major cities in East Java, Central Java (Madiun, Solo, and Malang). Ponorogo currently includes pathway for the transport of goods with southern cross. The existence of these path ways open up great opportunities forrevenue. Particularly for sectors that require transportation as a stimulant, such as agriculture, trade, services, and tourism. In addition, it also has opportunity to extend market for commodity exports to the region this region, in addition tolarge potential resources contained in this region.

Ponorogo leading sector are tourism sector, plantations, and agriculture. Priority development activities in the unit area of Madiun evelopment activities aimedat the trade, commercialservices, financial, manufacturing andother public services. Development activities in the surrounding regionis agri- 
cultural, plantation, and fisheries. Ponorogo is the producer of durian fruit, melon, mango and orange. Ponorogo has huge potential in agriculture, particularly forrice crops, types of vegetables such as beans, peas, onion, corn and soy bean. All of the abovetypes of plants, both in terms of productivity and total production per year havingan average value of production of the province, thus allowing it tobe used as a companion in the region leading commodity of Ponorogo agropolitan.

Identification Ponorogo agropolitan starts with an understanding of the existence of a basic physical condition, socio-economic, infrastructure and facilities, human resources, technology, commodities, agribusiness, agro-tourism, economic institutions, and social culture. It is more focused on the spatial aspects and agribusiness, as well as the region's development strategy into agropolitan. In order to improve the welfare of the community and local revenue should be autonomous agribusiness development plan with a regional and commodity approaches. With regard to agricultural commodities produced, it must have a comparative competitiveness principe and high dynamic competitif, then the existence of the product needs to be done with the extension and orientation to the market demand. Ponorogo in addressing these demands, economic potential development planto prioritize theim provement of agriculture and agribusiness approach agropolitan. Agribusiness commodity based on the concept that emphasizes the importance of choosing the coupled leading commodity position as a leading commodity product diversification. Leading commodities as an alternative product has a broad, both as primary and secondary products.

The basic concept is agropolitan area is the development of a particular region which has it's main agricultural activity, which is equipped with facilities and infrastructure and urban accessibility. This concept basically aims to provide accessibility of urban services in rural areas or in rural areas create a city. Thus farmers or rural communities do not necessarily have to go into town to meet daily needs as well as to obtain other services, both in the services related to production issues, marketing, Issues relating to the social, economic and cultural. Analysis of location determination Agropolitan area in the district, followed by determination of it's development strategy into an agropolitan in Ponorogo (Table 1).

In order to gain information about potential agricultural commodities in Ponorogo, it is necessary to use an analysis tool that LQ (Location Quotien). LQ is a technique used to measure the concentration ofan economic activity or sectorina region by comparing its rolein the regional economy to the role of economic activity/same sector the national level. In other words, the sector in a region by comparing its role in the regional economy to the role of economic activity/same sectorat the national level. The rationale behind of this method is as follows. For example, an industrial area there are two, namely A and B. Industry A serving local markets and markets outside the region $(\mathrm{X})$, the industry is called the industrial base. While industrial base Bisnon-local industry or industry, because only serve the local market. The rationale of this analysis tech- 
Table 1. Identifying Potential Agricultural Commodities in Ponorogo Regency

\begin{tabular}{llccccc}
\hline Commodity & $\begin{array}{c}\text { Types of } \\
\text { commodities }\end{array}$ & $\begin{array}{c}\mathrm{V}_{1} \\
\text { Production } \\
\text { Value } \\
\text { Commodities } \\
\text { (000 Ton) }\end{array}$ & $\begin{array}{c}\mathrm{V}_{\mathrm{t}} \\
\text { GDRP } \\
\text { Each Java } \\
\text { Commodity } \\
\text { (Million IDR) }\end{array}$ & $\begin{array}{c}\mathrm{V}_{1} \\
\text { East Java } \\
\text { Commodity } \\
\text { Production Value } \\
\text { (000,US \$) }\end{array}$ & $\begin{array}{c}\mathrm{V}_{\mathrm{t}} \\
\text { GDRP } \\
\text { Commodity in } \\
\text { East Java } \\
\text { (IDR) }\end{array}$ & LQ \% \\
\hline Coconut & Plantation & $6,484.94$ & $7,632,728.73$ & 273,961 & $7,632,728.73$ & 2,427 \\
\hline Cacao & Plantation & 496.22 & $7,632,728.73$ & 27,391 & $7,632,728.73$ & 2,167 \\
\hline Cow & Livestock & 86,442 & $9,341,723.33$ & $110,762,219$ & $9,341,723.33$ & 7,590 \\
\hline Red Onion & $\begin{array}{l}\text { Horticulture } \\
\text { (agriculture) }\end{array}$ & 10,788 & $54,463,942.77$ & 222,862 & $54,463,942.77$ & 4,850 \\
\hline Cabbage & $\begin{array}{l}\text { Horticulture } \\
\text { (agriculture) }\end{array}$ & 18,914 & $54,463,942.77$ & 47,158 & $54,463,942.77$ & 0,401 \\
\hline $\begin{array}{l}\text { Small } \\
\text { Capsicum }\end{array}$ & $\begin{array}{l}\text { Horticulture } \\
\text { (agriculture) }\end{array}$ & 24,613 & $54,463,942.77$ & 244,040 & $54,463,942.77$ & 1.129 \\
\hline $\begin{array}{l}\text { Orange } \\
\text { Pulung }\end{array}$ & $\begin{array}{l}\text { Horticulture } \\
\text { (agriculture) }\end{array}$ & 185,836 & $54,463,942.77$ & 362,680 & $54,463,942.77$ & 0.500 \\
\hline Salak & $\begin{array}{l}\text { Horticulture } \\
\text { (agriculture) }\end{array}$ & 8.700 & $54.463 .942,77$ & 76.356 & $54.463 .942,77$ & 1.597 \\
\hline
\end{tabular}

Source: Data Processing (2016)

nique is the basis of economic theory, as previously discussed above, which in essence is as follows. Industry A is called industrial base because in addition toserving the local market also do $\mathrm{X}$ that gave discordant greater than the contribution of industry to the GDP formation B and employment opportunities. The increase inper capita incomeinthe areadue toindustrial activities resulted in alocal market de mand willin crease out put, not only from industry A, but also the industry $B$. The increase in demand is further boostedthe industry's first B due to growth in industrial out put A. In other words, through the multiplier effect, the industry a gives a large positive impacton the economy of the area.

The analysis area used to determine the commodity base, distribution characteristics and its contribution as a producer of the commodity production (coconut, cocoa, cows, onion, cabbage, hot chilli peppers, lemon juice, salak) in support of the region's economy in the region (oil, cocoa, cows, onion, cabbage, hot chilli peppers, lemon juice, salak) does not necessarily indicate that the region is the base area of the commodity. Centers of commodities such as base sector (Table 1), through the approach of Location Quotient (LQ). LQ can be calculated through Production (coconut, cocoa, cows, onion, lettuce, hot chilli peppers, lemon juice, salak) ponorogo and GDP of each commodity (oil, cocoa, beef, onion, mustard, chili pepper, lemon juice, bark) of East Java. Similarly Production (coconut, cocoa, beef, onion, mustard, capsicum pepper, lemon juice, bark) and EastJava GDP each commodity (oil, cocoa, beef, onion, mustard, capsicu, lemon juice, bark) East Java (BPS, Ponorogo). Area of Coconut in Ponorogo distric thas great potential with the value of $\mathrm{LQ}=(2.427)$ where coconut plantation area of 827.44 hectares with production of $6,484.94$ tons and are scattered through out the District in Ponorogo, while the largest is the districts Ngrayun, Pulung, Sukorejo, Jenangan and Ngebel (Table 2). 
Table 2. Regional Center of Coconut Commodities

\begin{tabular}{clcc}
\hline No & Central areas & $\begin{array}{c}\text { Areas } \\
\text { (Ha) }\end{array}$ & $\begin{array}{c}\text { Percentage } \\
\text { (district) }\end{array}$ \\
\hline 1 & Ngrayun & 102,81 & 12.43 \\
2 & Pulung & 136,43 & 16.50 \\
3 & Sukorejo & 40,08 & 4.85 \\
4 & Jenangan & 57,35 & 6.95 \\
5 & Ngebel & 66,04 & 7.00 \\
\hline
\end{tabular}

Source: Data Processing (2016)

Table 2 clearly shows that the Pulung is the largest oil production area in Ponorogo, so that the area is an area of development in the oil commodity Agropolitan development of the area. Area of Cocoa in Ponorogo district has great potential with the value of $\mathrm{LQ}=(2.167)$, where coconut plantation area of 689.30 hectares with aproduction of 496.22 tons and are scattered throughout the District in Ponorogo, whilethe largest in the District Sawoo, Pulung, Jenangan, Ngebel (Table 3).

Table 3. Regional Center of Cacao Commodities

\begin{tabular}{clcc}
\hline No & Central areas & $\begin{array}{c}\text { Areas } \\
(\mathrm{Ha})\end{array}$ & $\begin{array}{c}\text { Percentage } \\
(\%)\end{array}$ \\
\hline 1 & Sawoo & 52.35 & 7.60 \\
2 & Pulung & 289.72 & 42.03 \\
3 & Jenangan & 105.27 & 15.27 \\
4 & Ngebel & 155.36 & 22.53 \\
\hline
\end{tabular}

Source: Data Processing (2016)

Table 3 shows that Pulung is the largest cocoa production centers in Ponorogo, so that the area is an area of developmentin thecocoacommodityAgropolitandevelopment of the area. Dairy Cow and broiler production in Ponorogo district have great potential with the value of $L Q=(7,59)$ where live stock production Cattle Dairy Cattle and 86 442 tonnes and are scattered throughout the district in Ponorogo, while the largest in the District Pudak, Soko and Pulung (Table 4).
Table 4. Regional Center for Animal Husbandry and Dairy Cow Cattle

\begin{tabular}{clcc}
\hline No & Central areas & $\begin{array}{c}\text { Production } \\
\text { (Ton) }\end{array}$ & $\begin{array}{c}\text { Percentage } \\
\text { (district) }\end{array}$ \\
\hline 1 & Pudak & 4.247 & 4,91 \\
2 & Sooko & 3.536 & 4,10 \\
3 & Pulung & 2.997 & 3,46 \\
\hline
\end{tabular}

Source: Data Processing (2016)

Table 4 show that the region is an area of central Pudak's Dairy and Cattle Ponorogo largest, so that the area is a developing area of the Center's Dairy and Cattle in the development of the area Agropolitan. Onion production in Ponorogo district mampunyai huge potential with the value of LQ $=$ (4.85) where the production of 10788 tonnes of onion scattered throughout the Districtin Ponorogo, while the largest in the District Sawoo, Pudak, Pulung, Mlarak and Sukorejo (Table 5).

Table 5. Regional Horticultural Crop Production Center Onion

\begin{tabular}{clcc}
\hline No & Central areas & $\begin{array}{c}\text { Production } \\
\text { (Ton) }\end{array}$ & $\begin{array}{c}\text { Percentage } \\
(\%)\end{array}$ \\
\hline 1 & Sawoo & 1.444 & 13,40 \\
2 & Pudak & 2.989 & 27,70 \\
3 & Pulung & 2.829 & 26,22 \\
4 & Mlarak & 1.391 & 12,90 \\
5 & Sukorejo & 1.050 & 9,75 \\
\hline
\end{tabular}

Source: Data Processing (2016)

Table 5 shows that the area is the production center Pudak Hortikulturt a Plant Red Onion largest Ponorogo, so that the area is a developing area in the development of commodity Red Onion Agropolitan region. Chilli production in Ponorogo district have huge potential with the value of $L Q=(1.129)$ where production amounted to 24,613 ton sof spicy chili spread through out the Districtin Ponorogo, while the largest in Sooko, Pudak, Pulung, Mlarak, Siman and Babadan (Table 6). 
Table 6. Regional Horticultural Crop Production Center shot chili

\begin{tabular}{clcc}
\hline No & Central areas & $\begin{array}{c}\text { Production } \\
\text { (Ton) }\end{array}$ & $\begin{array}{c}\text { Percentage } \\
\text { (district) }\end{array}$ \\
\hline 1 & Sooko & 5.796 & 23,55 \\
2 & Pudak & 7.435 & 30,20 \\
3 & Pulung & 2.521 & 10,25 \\
4 & Mlarak & 1.950 & 7,92 \\
5 & Siman & 1.703 & 6,91 \\
6 & Babadan & 1.066 & 4,33 \\
\hline
\end{tabular}

Source: Data Processing (2016)

Table 6 also shows that the Pudak a Horticultural crop production areas larges thot chili Ponorogo, so that the area is a hot chili commodity development areasint he region Agropolitan development. Production Salak in Ponorogo district has great potential value $=$ LQ (1.597) in which the production of 24,613 tons Salak scattered throughout the District in Ponorogo, while the largest in Sooko and Pulung (Table 7). It also shows that the Pulung a production center of Horticultural Crops largest Salak Ponorogo, so that the area is a developing area of horticultural crops in the development of the area Agropolitan of Salak.

Table 7. Regional Horticultural Crop Production Center Salak

\begin{tabular}{clcc}
\hline No & Central areas & $\begin{array}{c}\text { Production } \\
\text { (Ton) }\end{array}$ & $\begin{array}{c}\text { Percentage } \\
(\%)\end{array}$ \\
\hline 1 & Slahung & 637 & 3.66 \\
2 & Sooko & 4.248 & 24.42 \\
3 & Pulung & 8.695 & 49.98 \\
4 & Balong & 245 & 1.40 \\
\hline
\end{tabular}

Source: Data Processing (2016)

\section{Conclusion}

It can be concluded that several comodities namely coconut, cocoa, dairy, red onion have a high LQ value to support agropolitan development. This tells us to say that these commodities could be expect to help agropolitan development. In addition, it can improve equitable development between region by improving agricultural revitalization program, given the selected sector as the basis of community activity.

\section{References}

Afgani Y, Ahmad Y And Saad H (2012). Implementation Of Agropolitan Approach In Malaysia: Preliminary Study At Pulau Banggi, Prosiding International Conference On Construction, Facility And Asset Management (Iccfm). 21-22 Nov 2012. Padang, West Sumatera Indonesia.

Alice Bauxa, Julien Wegmüller, Annelie Holzkämper (2015). Exploring climatic impact on oilseed rape yield in Switzerland. Procedia Environmental Sciences 29 .P. 123.

Arsyad, M., (2010). The Dynamics of Cocoa Smallholders in Indonesia: An Application of Path Analysis for Poverty Reduction (Abstracts of Doctoral Thesis on Indonesian Economy). Bulletin of Indonesian Economic Studies, 46(2): 251-254.

Austin K. Baldwin, Steven R. Corsi, Laura A. De Cicco, Peter L. Lenaker, Michelle A. Lutz, Daniel J. Sullivan, Kevin D. Richards (2016). Organic contaminants in Great Lakes tributaries: Prevalence and potential aquatic toxicity. Science of the Total Environment 554-555 P: 42-52.

Anis Zakiah Mazlan, Hazilia Hussain, Mohamed Azwan Mohamed Z. (2016) . Potential Dermal Exposure Assessment of Farmers to HerbicideImazapic in an Agriculture Area. Procedia 
- Social and Behavioral Sciences 234: $144-153$.

Bahua, M.I., M. Arsyad, M.H. Jamil (2016). Farmers Community Empowerment through Institutional Strengthening of Rural Food Barn. International Journal of Agriculture System, 4(2):161-167.

Bosshard, A. A, (2000). Methodology and terminology of sustainability assessment and its perspective for rural planning. Agriculture, ecosystems, and environment Journal ; 77 P: 29-41.

Buang, A., Habibah, A., Hamzah, J., \& Ratnawati, Y. S. (2011). The agropolitan way of re-empowering the rural poor. World Applied Sciences Journal, 13(13 SPECIAL ISSUE), 1-6

Boonrawat Pruksanubal (2016). Land Use Transformation Process in Chachoengsao Province, Thailand. ProcediaSocial and Behavioral Sciences 222: $772-781$

C. Kenny (2005). Why Are We Worried About Income? Nearly Everything That Matters Is Converging World Development, 33 (1):1-19.

Daidullah, S. T. (2006). Strategi Pengembangan Agropolitan Dinas Tanaman Pangan Hortikultura, Perkebunan dan Peternakan Kabupaten Buol. Yogyakarta. Thesis: Program Studi Magister Manajemen Agribisnis Sekolah Pascasrjana Universitas Gajahmada.2006.

Dirjen BPPHP Deptan (2002). Rencana Strategis Ditjen BPPHP 2001. Departemen Pertanian. Jakarta.

Djakapermana, R D. (2007). Pengembangan Kawasan Agropolitan Dalam Rangka Pengembangan Wilayah Yang Berba- sis Rencana Tata Ruang Wilayah Nasional. Jakarta. Direktorat Jendral Penataan Ruang Departemen Pemukiman dan Prasarana Wilayah R.I.

Douglass M. (1981). Agropolitan Development: An Alternative for Regional Development in Asia. Himalaya Review, 13:37-71.

ECERDC (2009) “Agropolitan; Bermulanya Masa Depan Gemilang”. Majlis Pembangunan Wilayah Ekonomi Pantai Timur. Kuala Lumpur.

Edwin N, M. and H. Usman. (2007). Proses Peneltian Kualitatif. Jakarta. FE UI

Friedmann J. (1981). The active community: Toward a political-territorial framework for rural development in Asia. Economic Development and Cultural Change 29:235-261.

Gumbira Said, E., A. Harizt Intan. (2001). Manajemen Agribisnis. Ghalia, Indonesia. Jakarta.

Hamenda. J. (2007). Peranan Investasi dalam mengembangkan Kawasan Agropolitan yang berbasis Komoditas. Konsultan PT. Prakarsa Internasional. Jakarta.

Hartono, N. Jakarta. (2008). Penguatan Kelembagaan Petani. Dalam Pemanfaatan Air Irigasi Dalam Pengembangan Agribisnis (Study 98 Kasus di Kabupaten Tasikmalaya). Pusat Study dan Pengembangan Sumberdaya Air dan Lahan (PSDAL), LP3ES. Jakarta.

Hermawan, R. (2008). Membangun Sistem Agribisnis. Agroinfo. Yogyakarta. 2008.

Khaled S. Balkhair, Muhammad Aqeel Ashraf. (2016). Field accumulation risks of heavy metals in soil and veg- 
etable crop irrigated with sewage water in western region of Saudi Arabia. Saudi Journal of Biological Sciences 23, S32-S44

K.M. Barlowa,, B.P. Christya, G.J. O’Leary, P.A. Riffkin , J.G. Nuttall. (2015). Simulating the impact of extreme heat and frost events on wheat crop production: A review . Field Crops Research 171 P: $109-119$

Li, M. (2009). The choice of Sustainable development model of China's. Agriculture .Asian Social Science, 5 P: 91-93.

Miladis M. Afidchaoa, C.J.M. Mustersa, Ada Wossinkc, Orlando F. Balderamad, Geert R. de Snoo (2014). Analysing the farm level economic impact of GM corn in the Philippines. NJAS - Wageningen Journal of Life Sciences 70-71 P: 113-121.

Michael W. Palace, Franklin B. Sullivan, Mark J. Ducey, Robert N. Treuhaft, Christina Herrick, Julia Z. Shimbo, Jonas Mota-E-Silva (2015). Estimating forest structure in a tropical forest using field measurements, a synthetic model and discrete return lidar data. Remote Sensing of Environment 161: $1-11$.

John W. Mc Arthura, Gordon C. McCordb (2017). Fertilizing growth: Agricultural inputs and their effects in economic development.

Rahman, T., Mittelhammer Rc, Wandschneider Pr. (2011) "Measuring Quality of Life Across Countries: A Multiple Indicators And Multiple Causes Approach." The Journal of Socio-
Economics. 40: 43-52.

Seragaldin (1994). Making development sustainable: from concept to action. The International Bank for Reconstruction and Development/The World Bank Washington DC. USA; 1994.

Suthathip Riwthong, Pepijn Schreinemachers, Christian Grovermann, Thomas Berger, (2016). Agricultural commercialization: Risk perceptions, risk management and the role of pesticides in Thailand. Kasetsart Journal of Social Sciences Xxx P: 1- 9.

Robert K. Y. (2002). Studi Kasus Desain \& Metode. PT. Raja Grafido Persada. Cet. I 1996, Edisi Revisi. Jakarta.

Robert G. Berger, MelissaWhitfield Aslund, Greg Sanders, Michael Charlebois, Loren D. Knopper, Karl E. Bresee (2016). A multiple lines of evidence approach for the ecological risk assessment of an accidental bitumen release from a steam assisted gravity drainage. Science of the Total Environment 542 P: 495-504.

Ruchyat D. D. (2007). Pengembangan Kawasan Agropolitan Dalam Rangka Pengembangan Wilayah Yang Berbasis Rencana Tata Ruang Wilayah Nasional. Direktor Jenderal Penataan Ruang Departemen Pemukiman dan Prasarana Wilayah R.I. Jakarta.

Yusof Ahmad, Hamid Saad, Eusoff, Yendo Afgani, Naeemah Yusof. (2014). Quality of Life amongst Agropolitan Participant Project: A Malaysian experience. Procedia - Social \& Behavioral Sciences 153 P: $479-490$. 